\title{
Bernd Zimmermann (1946-2018)
}

Our great friend, the always helpful supporter of the Hungarian mathematics didactics, Bernd Zimmermann, the retired mathematics didactics professor of Friedrich Schiller University of Jena, passed away on 19th of July 2018. After a short chronology of his life, we remember some of the many areas of his work with strong Hungarian connections.

\section{Chronology of his life}

Professor Zimmerman was born in 1946 in Hamburg. He graduated as Mathematics-Physics teacher in 1973, and started his remarkable career at the University of Paderborn, where he was an assistant lecturer between 1973 and '78. He got his $\mathrm{PhD}$ degree in 1977 in the field of analysis of mathematical problemsolving processes. He was teaching mathematics and physics in secondary school between 1978 and '85. Meanwhile, he was fostering those mathematically gifted in study groups since 1983 in Hamburg, where he was assistant lecturer at the University between 1985 and '91. There he habilitated in 1992, with the topic of: "Heuristics as an element of mathematical thinking and learning processes" ("Heuristik als ein Element mathematischer Denk- und Lernprozesse"). He was visiting lecturer at the University of Greifswald between 1992 and '93. He was mathematics-didactics professor at the Friedrich Schiller University of Jena and head of Mathematics?didactics department from 1993 up until his retirement in 2011. 


\section{His main research interests}

Professor Zimmerman had a deep interest in mathematical problem-solving processes, heuristics as well as historical aspects. He invested great amount of time and energy into fostering mathematically talented students. He was always searching for creativity in elementary mathematics. While he was teaching mathematics and the philosophy of science, he was also researching mathematical convictions, beliefs, the mental picture of mathematics, and the ideas of teaching of mathematics.

\section{Organizational memberships and positions he held}

Professor Zimmermann was member of the Gesellschaft für Didaktik der Mathematik (GDM), Verein zur Förderung des mathematischnaturwissenschaftlichen Unterrichtes (MNU), Deutsche Mathematikervereinigung (DMV), im Vorstand der "William-Stern-Gesellschaft für Begabungsforschung und Begabtenförderung e. V.", NCTM (National Council of Teachers of Mathematics).

Beside these memberships, he was also reviewer of the VW-Stiftung, "Journal für Mathematikdidaktik", reviewer for choosing of lectures for PME ("Psychology in Mathematics Education").

He was also associate editor of the international journals "Teaching Mathematics and Computer Science", "The Electronic Journal of Mathematics and Technology", and "The Teaching of Mathematics".

He will be sadly missed in all of the circles above.

His role in the relationships between universities Jena and Budapest

In the frame of the contract between Friedrich Schiller University of Jena and Eötvös Loránd University of Budapest, a close working relationship has been established between the departments of mathematics didacticians of both universities. This cooperation has more than 50 years history as of now, with mutual professional visits, students exchanges, international conferences being organised at both of the universities and joint research activities in many scientific projects. Thanks to Professor Zimmermann's dedication and influential role, this cooperation has become even closer since 1993. 
His help in establishing the PhD school in Didactics of Mathematics in Hungary

The Mathematics Didactics PhD program of the University of Debrecenas the sub-program of the Mathematics PhD program-started in 1999. Before that time, the only way to get a scientific degree for a mathematics didactician was either from mathematics or from pedagogy. I participated in the program from the start as a founding member. Professor Zimmermann helped us a lot from the beginning in the development of professional bases as well as in the research methodological questions. He consulted many-many times with Hungarian $\mathrm{PhD}$ students at conferences and was sending them relevant articles and books. He was an associate editor of our scientific journal "Teaching Mathematics and Computer Science" from its inception. He was of great help many-many times with supportive but demanding criticism when reviewing scientific articles of Hungarian PhD students. He also demonstrated the highest standards of scientific work with at least two articles. Some of us fortunate can remember his talks as well. For example, the PhD School of Mathematics Didactics of the University of Debrecen organizes the yearly conference "Researches in Didactics of Mathematics and Computer Sciences" since 2009. Professor Zimmermann delivered an influential plenary talk on the MIDK Conference in Levoca (Slovakia) in 2012, with the title "On modern Trends in international Mathematics Education and some neglected Research Domains".

His passing is leaving a void that is hard to fill.

His role in the conference series "Problem Solving in Mathematics Education (ProMath)"

This conference series started in 1999, and its founders were: Professor Günter Graumann from the University of Bielefeld, Professor Erkki Pehkonen from the University of Helsinki, and Professor Bernd Zimmermann. This is a conference organised every year, in various countries. We, Hungarians joined this conference in 2005, and have been organising five meetings until now: in Debrecen (2005), Révkomárom (2006), Budapest (2009 and 2017) and Eger (2013). These conferences were good opportunities for Hungarian PhD students to demonstrate their research results but also for consultations with professor Zimmermann. The conference proceedings is an important publication forum for our $\mathrm{PhD}$ students. 
Their articles would be reviewed by two international colleagues. The possibility of an international outlook, to be able to observe and consider trends seen abroad and not only the Hungarian perspective is very-very important for our PhD students. Professor Zimmermann was always willing to share his critical but always helpful remarks with our $\mathrm{PhD}$ students during these reviews.

His insights will be sadly missed.

\section{His connection to George Polya}

Heuristics played a central role in Professor Zimmermann's research of mathematics history. He was a great fan and enthusiastic researcher of Polya. Very often he commented the matters of teaching mathematical problem solving with the enthusiastic exclamation: "Of course Polya!". He was the editor of two special Polya issues of the journal "Der Mathematikunterricht" (Teaching Mathematics 2, 3/2010). Éva Vásárhelyi, Kinga Szűcs and myself have written one study each about Polya's influence on Hungarian mathematics teaching. On the conference of GDM (German Society of Didactics of Mathematics) in Budapest, 2008, Professor Zimmerman was a plenary speaker and delivered a talk about George Polya. Fostering of talented pupils was a central topic in our relationship and formed a strong bond between us. Professor Zimmermann joined the Arbeitskreis Mathematiklehren und lernen in Ungarn (Group of Teaching and Learning of Mathematics in Hungary) from its inception in 2015. He delivered a talk on the meeting of the group, and reviewed the studies for the proceedings.

\section{He as mathematics schoolbook editor and author}

Professor Zimmerman was the editor and the author of many chapters of the mathematics school textbook series MatheNetz for secondary school Grades 511. The symbol of the book series is a regular eight-sided polygon with its sides and diagonals. There is a correspondence between the vertices and activities in mathematics: Ordering-Inventing-Playing-Constructing-Applying-CalculatingEvaluating-Arguing. Professor Zimmermann gave away many copies of this textbook series as gifts not only for us but also for our PhD students as well. The textbook provides good examples of problem oriented teaching, and has nice historical parts too. 


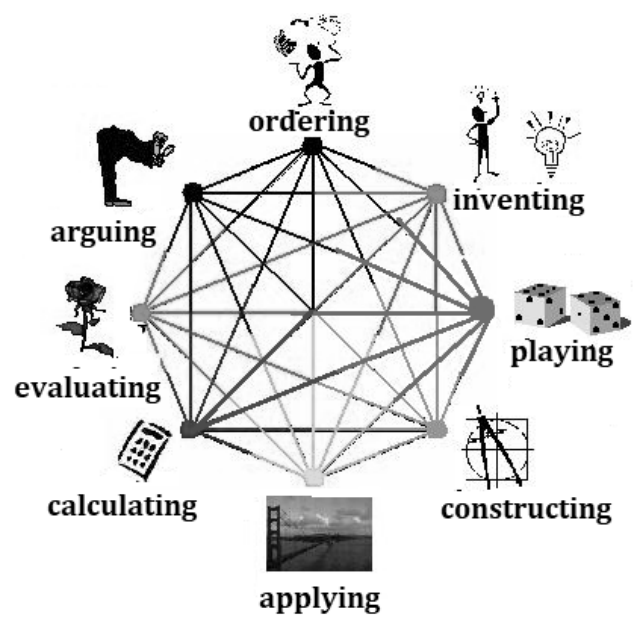

A very rich life has come to an end. A lot of students, colleagues, friends will preserve the smile, helpfulness, many-many good ideas and suggestions of Professor Zimmermann. Rest in peace!

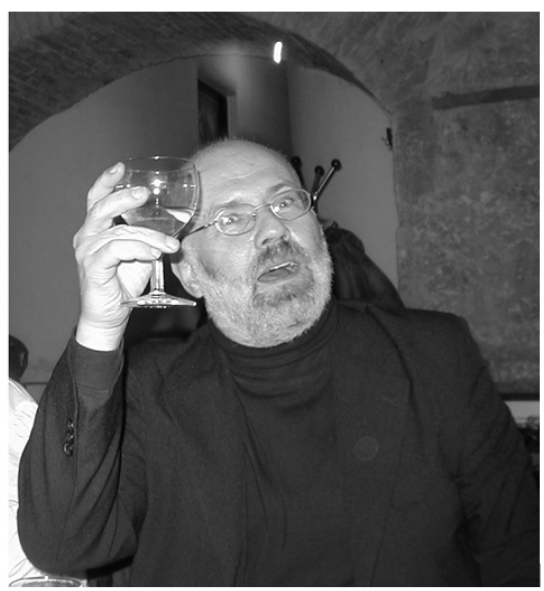

ANDRÁS AMBRUS

RETIRED ASSOCIATE PROFESSOR,

EÖTVÖS LORÁND UNIVERSITY, BUDAPEST,

MATHEMATICS TEACHING AND EDUCATION CENTER

E-mail: ambrus@cs.elte.hu 